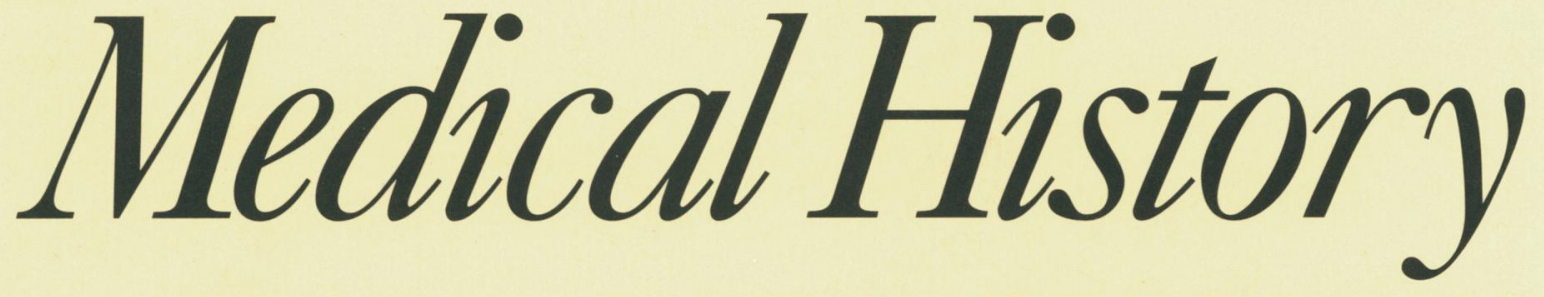

A Quarterly Journal Devoted

to the History of Medicine and Related Sciences

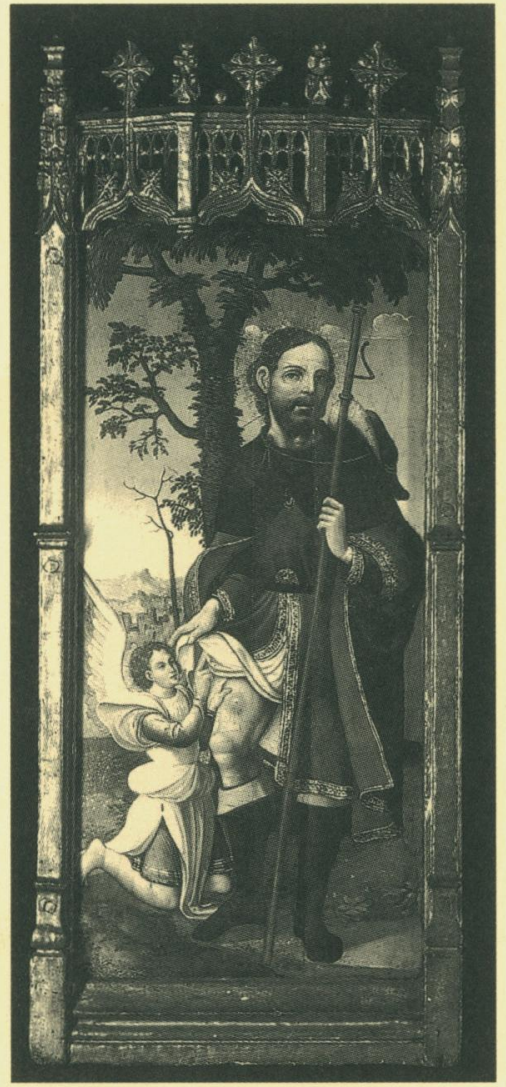

Volume 47 • Number 4 • October 2003 


\section{Medical History}

\section{CONTENTS}

\section{Articles}

"In These Perilous Times": Plague and Plague Policies in Early Modern Denmark PETER CHRISTENSEN

The Intimate Experience of the Body in the Eighteenth Century: Between Interiority and Exteriority

Professional Ambitions, Political Inclinations, and Protein Problems:

Conflict and Compromise in the BMA Nutrition Committee

1947-1950

MARK W BUFTON, DAVID F SMITH and VIRGINIA BERRIDGE

The Mexican Response to high Altitudes in the 1890s: The Case of a

Physician and his "Magic Mountain"

ANA CECILIA RODRÍGUEZ DE ROMO and JOSÉ ROGELIO PÉREZ PADILLA

News, Notes, and Queries

\section{Essay Review}

Griffith Edwards (ed.), Addiction: evolution of a specialist field

David F Musto and Pamela Korsmeyer, The quest for drug control: politics and federal policy in a period of increasing substance abuse, 1963-1981

H B Spear, Heroin addiction care and control: the British system 1916-1984 ed. Joy Mott 


\section{Contents}

Book Reviews

Janet Browne, Charles Darwin: the power of place

W H BROCK

Harry Oosterhuis, Stepchildren of nature: Krafft-Ebing, psychiatry, and the making of sexual identity

ANDREW SCULL

Henry L Minton, Departing from deviance: a history of homosexual rights and emancipatory science in America IVAN CROZIER

Roy Porter, Bodies politic: disease, death and doctors in Britain 1650-1900 KEIR WADDINGTON

Joan Lane, $A$ social history of medicine: health, healing and disease in England 1750-1950

Ilana Löwy and John Krige (eds), Images of disease: science, public policy and health in post-war Europe MARTIN GORSKY

Alexandra Minna Stern and Howard Markel (eds), Formative years: children's health in the United States 1880-2000 LINDA BRYDER

Caroline Jean Acker, Creating the American junkie: addiction research in the classic era of narcotic control MIKE JAY

David Healy, The creation of psychopharmacology ERIKA DYCK

Jennifer Stanton (ed.), Innovations in health and medicine: diffusion and resistance in the twentieth century CARSTEN TIMMERMANN

J S Cameron, $A$ history of the treatment of renal failure by dialysis GEOFFREY RIVETT

N D A Kemp, 'Merciful release': the history of the British euthanasia movement JOHN WELSHMAN

Terrie M Romano, Making medicine scientific: John Burdon Sanderson and the culture of Victorian science CHRISTOPHER LAWRENCE

Andrew Berry, Infinite tropics: an Alfred Russel Wallace anthology JOHN C WALLER 


\section{Contents}

Eric Gruber von Arni, Justice to the maimed soldier: nursing, medical care and welfare for sick and wounded soldiers and their families during the English civil wars and Interregnum, 1642-1660 PHILIP K WILSON

Joan Druett, Rough medicine: surgeons at sea in the age of sail

FIONA A MACDONALD

Jürgen Helm and Annette Winkelmann (eds), Religious confessions and the sciences in the sixteenth century

Karen Jolly, Catharina Raudvere, Edward Peters, Witchcraft and magic in Europe. Volume 3: The Middle Ages CORNELIUS O'BOYLE

Lawrence I Conrad and Dominik Wujastyk (eds), Contagion: perspectives from pre-modern societies ANGELA KI CHE LEUNG

Vivian Nutton (ed.), Medicine in the Renaissance city

DAVID GENTILCORE

Irmgard Müsch, Rainer Willmann, and Jes Rust, Albertus Seba's Cabinet of natural curiosities: Locupletissimi rerum naturalium thesauri, 1734-1765

CLAUDIA STEIN

Zohar Amar, The history of medicine in Jerusalem

EFRAIM LEV 


\section{Medical History}

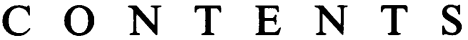

Volume 47 • Number 4 • October 2003

Articles

"In These Perilous Times": Plague and Plague

Policies in Early Modern Denmark

PETER CHRISTENSEN

The Intimate Experience of the Body in the

Eighteenth Century: Between Interiority and

Exteriority

SÉVERINE PILLOUD and MICHELINE LOUIS-COURVOISIER

Professional Ambitions, Political Inclinations, and

Protein Problems: Conflict and Compromise in the BMA Nutrition Committee 1947-1950

MARK W BUFTON, DAVID F SMITH and VIRGINIA BERRIDGE

The Mexican Response to high Altitudes in the 1890s: The Case of a Physician and his "Magic Mountain" ANA CECILIA RODRÍGUEZ DE ROMO and JOSÉ ROGELLO PÉREZ PADILLA

Essay Review

History and Twentieth-Century Drug Policy: Telling True Stories? VIRGINIA BERRIDGE

Book Reviews

Index 


\section{CONTENTS}

\section{JANUARY}

Some Ways into the New Millennium

ANNE HARDY

1

Articles

New Light on Dr Thomas Moffet: The Triple Roles of an Early Modern

Physician, Client, and Patronage Broker

FRANCES DAWBARN

"Russian Nervousness": Neurasthenia and National Identity in

Nineteenth-Century Russia

LAURA GOERING

The Government of Israel and the Health Care of the Negev Bedouin under

Military Government, 1948-1966

SHIFRA SHVARTS, JEFREY BORKAN, MOHAMAD MORAD, MICHAEL SHERF

The Medical Activities of the London Jews' Society in Nineteenth-Century Palestine YARON PERRY and EFRAIM LEV

Short Article

Surgical Instruments in the Taxila Museum

NASIM H NAQVI

89

Comment

Spanish Toxic Oil Syndrome

RICHARD DOLL

Obituary

Owsei Temkin

VIVIAN NUTTON

101

News, Notes, and Queries

104

Essay Review

Reconstructing History

GUENTER B RISSE

108

Book Reviews

Book Notices

\section{APRIL}

Articles

Angels or Aliens? Refugee Nurses in Britain, 1938 to 1942 
A Shadow of Orthodoxy? An Epistemology of British Hydropathy, 1840-1858

Medicine, Health and Economic Development: Promoting Spa and Seaside Resorts in Scotland c. 1750-1830

ALASTAIR DURIE

Dangerous Yardstick? Early Cost Estimates and the Politics of

Financial Management in the First Decade of the National Health

Service

TONY CUTLER

Illustrations from the Wellcome Library

Joseph Fenton and his Books

DAVID PEARSON

News, Notes, and Queries

Essay Review

The Territory between Life and Death

VIVIENNE LO

Book Reviews

\section{JULY}

Articles

Beyond "Bad News": The Diagnosis, Prognosis and Classification of

Lymphomas and Lymphoma Patients in the Age of Biomedicine

(1945-1995) PETER KEATING and ALBERTO CAMBROSIO

To Kill or not to Kill: The Eradication of Contagious Bovine

Pleuro-Pneumonia in Western Europe JOHN FISHER

Part of a Scientific Master Plan? Paul Ehrlich and the Origins of his

Receptor Concept

CAY-RÜDIGER PRÜLL

More than Just a Propagandist for Tea: Religious Argument and Advice on a Healthy Life in the Work of the Dutch Physician Cornelis Bontekoe (1647-1685) CHRISTOPH SCHWEIKARDT

Illustrations from the Wellcome Collections

Medicine Man: The Forgotten Museum of Henry Wellcome KEN ARNOLD and DANIELLE OLSEN

Obituary

Eric Gaskell JOHN SYMONS

News, Notes, and Queries 


\section{OCTOBER}

Articles

"In These Perilous Times": Plague and Plague Policies in Early Modern

Denmark PETER CHRISTENSEN

The Intimate Experience of the Body in the Eighteenth Century: Between Interiority and Exteriority

SÉVERINE PILLOUD and MICHELINE LOUIS-COURVOISIER

Professional Ambitions, Political Inclinations, and Protein Problems:

Conflict and Compromise in the BMA Nutrition Committee 1947-1950

MARK W BUFTON, DAVID F SMITH and VIRGINIA BERRIDGE

The Mexican Response to high Altitudes in the 1890s: The Case of a Physician and his "Magic Mountain"

News, Notes, and Queries

Essay Review

History and Twentieth-Century Drug Policy: Telling True Stories?

Book Reviews

Index 


\title{
Medical History
}

\author{
EDITORS: Harold J Cook, MA, PhD, and Anne Hardy, MA, DPhil
} ASSISTANT EDITOR: Caroline Tonson-Rye, MA

\author{
EDITORIAL BOARD: Prof. W H Anderson \\ Prof. David Arnold \\ Prof. W H Brock \\ Prof. W F Bynum \\ Prof. Bernardino Fantini \\ Prof. Christopher Hamlin \\ Prof. Colin Jones \\ Dr S Lock
}

Medical History is devoted to all aspects of the history of medicine, but is concerned primarily with the evolution of scientific and social concepts in medicine, as well as with the many disciplines such as economics, ethnology, literature, philosophy, politics, theology, science, technology, etc., that impinge upon it. It is published quarterly in January, April, July, and October.

\section{EDITORIAL OFFICE}

Manuscripts, review copies of books, and correspondence concerning permissions and editorial matters should be addressed to The Editors, Medical History, The Wellcome Trust Centre for the History of Medicine at UCL, Euston House, 24 Eversholt Street, London NW1 1AD, UK.

E-mail: c.tonson-rye@ucl.ac.uk

\section{SUBSCRIPTIONS, SALES, AND ADVERTISING}

Enquiries regarding institutional subscriptions, orders for the annual Supplement, and advertising should be addressed to Professional \& Scientific Publications, BMA House, Tavistock Square, London WClH 9JR, UK. Tel.: +44 (0)2073874499.

\section{ANNUAL SUBSCRIPTION RATES:}

Individuals wishing to subscribe to Medical History should write to Maria Ketley, Wellcome Building, 183 Euston Road, London NW1 2BE, UK. Tel.: + $44(0) 20$ 76118500 ; e-mail: fwlc@wellcome.ac.uk. The individual subscription rate which includes membership of The Friends of the Wellcome Library and Centre is $£ 30.00$ (UK), $£ 34.00$ (overseas) for ordinary members.

Institutional subscribers (Medical History only) $£ 100$ (single rate worldwide), \$153 (USA, direct orders only). Institutional subscribers (Medical History and annual Supplement) $£ 132$ (single rate worldwide), \$203 (USA, direct orders only).

All subscribers (annual Supplement) $£ 32$ (single rate worldwide), $\$ 50$ (USA, direct orders only).

(Airmail rates on request.)

Single issues of the current and previous volumes may be purchased at $£ 12.00$ (including postage) each. Note: Pre-1966 issues are not available. 1966-1990 issues, where available, may be obtained by direct application to the Wellcome Library, 183 Euston Road, London NW1 2BE, UK. Issues from 1991 onwards may also be obtained from Professional \& Scientific Publications, BMA House, Tavistock Square, London WC1H 9JR, UK. Tel.: +44 (0)2073874499.
Dr Ilana Löwy

Prof. A-H Maehle

Prof. Vivian Nutton

Dr Harry Oosterhuis

Prof. Matthew Ramsey

Prof. Andrew Scull

Prof. J H Warner

Prof. Michael Worboys

Microform $(16 \mathrm{~mm}$ microfilm, $35 \mathrm{~mm}$ microfilm, $105 \mathrm{~mm}$ microfiche) and photocopies are available from Bell \& Howell Company, 300 North Zeeb Road, Ann Arbor, Michigan 48106, USA. Photocopies also available from UnCover Company, 3801 E Florida, Suite 200, Denver, CO 80210, USA.

Periodicals postage paid Rahway, NY Postmaster: send address changes to: Medical History, c/o Mercury Airfreight International Ltd, 365 Blair Road, Avenel, NJ 07001, USA.

\section{INFORMATION FOR CONTRIBUTORS}

Articles should not exceed 10,000 words in length. Editions of previously unpublished texts and documents as well as short papers will also be considered for publication. No paper will be considered if it is not satisfactorily documented. The Editors reserve the right to make stylistic or bibliographical emendations.

The following notes are not intended to be comprehensive: would-be contributors are strongly recommended to use the style sheet, available from the Assistant Editor, for guidance. Manuscripts must be submitted in duplicate, with double spacing and wide margins: the author should retain a copy. References must be typed with double spacing and arranged by number in order of their citation in the text: strict adherence to the standard form is required. Four illustrations are allowed free of charge; additional illustrations will be reproduced at the Editors' discretion and will be charged to the author. Each caption must include particulars of the source of the illustration and should be typed on a separate sheet.

Each contributor will receive a proof, which should be corrected and returned to the Assistant Editor as quickly as possible. Any changes other than the correction of typographical errors will be charged to the author. Authors will receive 25 offprints, and a copy of the journal, free of charge. Particulars of the cost of additional offprints will be sent before publication, and orders must be made by return.

Copyright $($ ) The Trustee of the Wellcome Trust, 2003. All Rights Reserved. No part of this publication may be reproduced, stored in a retrieval system, or transmitted, in any form or by any means, electronic, mechanical, photocopying, recording or otherwise, without the prior permission of The Wellcome Trust. 


\section{Medical History}

A Quarterly Journal Devoted to the History of Medicine and Related Sciences

Editors:

Harold J Cook, MA, PhD

Anne Hardy, MA, DPhil

Volume $47 \cdot 2003$ 